\title{
A PAISAGEM DO PANTANAL E A RURALIDADE NAS MINAS DO CUIABÁ (PRIMEIRA METADE DO SÉCULO XVIII)
}

\author{
Tiago Kramer de Oliveira \\ Doutorando em História Econômia pela Faculdade de Filosofia, Letras e Ciências \\ Humanas da Universidade de São Paulo; professor substituto na Universidade do Estado do Mato \\ Grosso e bolsista Capes
}

\section{Resumo}

Este artigo analisa a formação de ambientes rurais no contexto das conquistas portuguesas no centro da América do Sul, na primeira metade do século XVIII, e as implicações desta "formação" na construção (em suas várias dimensões) de um ambiente social reconhecido como Pantanal.

\section{Pallavras-chave}

Conquistas portuguesas $\bullet$ história agrária $\bullet$ Pantanal.

\section{Correspondência}

Departamento de História, Universidade Estado do Mato Grosso - Campus Jane Vanini Av. São João s $/ \mathrm{n}^{0}$ - Cavalhada

Cáceres - Mato Grosso - Brasil

CEP 78200-000

E-mail: kramer@usp.br 


\title{
THE PANTANAL LANDSCAPE AND THE RURALITY IN THE CUIABA MINES (FIRST HALF OF THE EIGHTEENTH CENTURY)
}

\author{
Tiago Kramer de Oliveira \\ Doctorate Student in Economic History in the Faculdade de Filosofia, Letras e \\ Ciências Humanas da Universidade de São Paulo; substitute professor at Universidade do Estado do \\ Mato Grosso and fellow Capes
}

\begin{abstract}
This article analyzes the formation of rural areas in the context of the Portuguese conquests in the center of South America in the first half of the eighteenth century, and the implications of this "formation" in the construction (in its various dimensions) of a social environment recognized as Pantanal.
\end{abstract}

Keywords

Portuguese conquests • agrarian history $\bullet$ Pantanal.

\section{Contact}

Departamento de História, Universidade Estado do Mato Grosso - Campus Jane Vanini Av. São João s $/ n^{\circ}$ - Cavalhada

Cáceres - Mato Grosso - Brazil

CEP 78200-000

E-mail: kramer@usp.br 
Nas enciclopédias, dicionários e em obras acadêmicas de especialistas, o Pantanal quase sempre é definido como um bioma, e sua descrição começa com "uma planície...". Esta definição aponta para características de um ambiente natural que interage com os ambientes sociais ou, como alguns afirmam, sofre a ação antrópica. Por este ambiente, palco movimentado por um incessante vai e vem de águas, passaram ao longo dos séculos uma diversidade de personagens que por estas mesmas águas (re)construíram suas histórias.

Ao historiador restaria, portanto, reconstruir estas histórias, ou seja, analisar o desenrolar de tempos sobre um espaço. Parece-nos, contudo, possível estabelecer outro tipo de relação entre tempo e espaço. A visão do Pantanal como um ambiente natural ignora um conjunto de práticas que construíram o Pantanal, vozes que ficam sufocadas por baixo de uma tábua rasa. $\mathrm{O}$ silêncio não apenas ignora, o silêncio é uma violência, não é ingênuo ou neutro, mas carregado de intencionalidades, de afirmação de uma autoridade sobre o espaço. Uma autoridade que motiva e legitima práticas. Acima da tábua é edificado um conjunto de representações ${ }^{1}$ sobre a presença antrópica que age na construção da memória do presente sobre o passado e que fazem emergir identidades forjadas, paisagens idealizadas e personagens míticos, como o homem pantaneiro, resultado, como os bois e os cavalos, de uma adaptação ao ambiente natural. Memória ancorada no rótulo tradicional que preenche de sentido, homogeneidade e continuidade as lacunas e imprecisões desta mesma memória.

O Pantanal que analisamos aqui emerge como um conjunto de inscrições no espaço, no contexto das conquistas portuguesas no centro da América do Sul. Interessa-nos particularmente reconstruir aspectos da estrutura agrária que são reveladoras de relações socioespaciais que contribuem para provocar fendas no silêncio e fazer emergir uma história muito diversa dos discursos que inventaram o Pantanal nas últimas décadas. O território ao centro da América do Sul, onde espacializaram-se ambientes coloniais luso-americanos, era percorrido por vassalos portugueses desde pelo menos o final do século XVII. Estes, atraídos pela possibilidade de aprisionarem ameríndios, adentravam cada vez mais ao interior da América. No entanto, foi somente com os descobrimentos auríferos no rio Coxipó-mirim, afluente do rio Cuiabá, a partir de pelo menos 1716, que foram formados ambientes coloniais fixos. Concomitantemente aos descobertos auríferos,

Utilizamos neste texto o conceito de representações sociais da forma como é definido por Chartier: "(...) esquemas intelectuais, que criam as figuras graças às quais o presente pode adquirir sentido, o outro tornar-se inteligível e o espaço ser decifrado". CHARTIER, Roger. História cultural: entre prática e representações. Lisboa: Ed. Difel, 1990, p. 17. 
formaram-se ambientes rurais que se localizavam ao longo dos rios que levavam às minas e também nos arredores das vilas e arraiais. A cada vez mais efetiva presença luso-americana na região e a articulação desta com outras partes da América portuguesa, possibilitou que, entre 1716 e 1727, a colonização consolidasse posições portuguesas no vale do rio Cuiabá próximo aos domínios hispânicos.

Além dos interesses dos colonos, também havia, desde 1718, a intenção formal do Conselho Ultramarino em fundar colônia nas Minas do Cuiabá. ${ }^{2}$ Ainda segundo Carlos Rosa "em fins de 1721, o bispo do Rio nomeou vigário da vara (juiz eclesiástico) para Cuiabá. Em 172,3 criou freguesia ou comarca eclesiástica no Cuiabá, sediada na Igreja Bom Jesus, elevada a matriz. Em junho o rei mandou "fundar vila no Cuiabá"”. ${ }^{3}$ A ordem real de "fundar vila" só foi cumprida em 1727, com a vinda a Cuiabá do governador da capitania de São Paulo, Rodrigo César de Meneses.

Apesar de não haver exploração aurífera considerável no rio Cuiabá, mas em seus afluentes, as minas da região foram sempre referenciadas como "minas do Cuiabá", topônimo que se confundia, até 1734, com o termo (o que hoje chamaríamos de área do município) da Vila Real. As minas do Cuiabá estavam administrativamente submetidas à capitania de São Paulo e, em nível local, à câmara, instituição imperial portuguesa que intermediava relações institucionais entre o local, o colonial e o metropolitano. A expansão das conquistas possibilitou que, a partir de 1734, houvesse novos descobertos em direção oeste da Vila Real, nas minas que ficaram conhecidas com o topônimo Mato Grosso.

Estas duas espacialidades, minas do Cuiabá e minas do Mato Grosso, passaram a compor o termo da Vila do Cuiabá até a criação da capitania de Mato Grosso, em 1748 (efetivada em 1751), e da Vila Bela da Santíssima Trindade, em 1752, já na segunda metade do século XVIII. O Pantanal, portanto, era parte das minas do Cuiabá e integrava o termo da Vila Real do Senhor Bom Jesus do Cuiabá.

\section{O sertanismo e a conquista dos territórios ameríndios}

O que motivava a invasão por colonos portugueses, principalmente advindos da capitania de São Paulo, nos territórios ameríndios no centro da América do Sul

2 ROSA, Carlos Alberto. A Vila Real do Senhor Bom Jesus do Cuiabá. Vida urbana em Mato Grosso no século XVIII: 1722-1808. Tese de doutorado em História Social. Departamento de História/FFLCH, USP, 1996, p. 65.

3 ROSA, Carlos Alberto. O urbano colonial na terra da conquista. In: ROSA, Carlos Alberto e JESUS, Nauk Maria de. A terra da conquista: história de Mato Grosso colonial. Cuiabá: Ed. Adriana, 2003, p. 15. 
era a reprodução de atividades que compunham o que se convencionou denominar de sertanismo. O sertanismo pode ser definido além da simples execução de atividades, como o aprisionamento e venda de ameríndios como escravos ou a procura e exploração de metais preciosos. As práticas sertanistas devem ser compreendidas articuladas a uma série de relações econômicas e sociais ${ }^{4}$ sendo parte de um sistema de relações políticas, definidas pela posição do Brasil como colônia de Portugal, articuladas com o processo de expansão da economia europeia que, do ponto de vista econômico, possibilitava a mobilização e reprodução de capitais e, do ponto de vista social, provocou uma série de rupturas, como desterritorializações de sociedades ameríndias e reterritorializações da sociedade colonial.

O próprio termo sertanismo tende a mascarar este caráter eminentemente mercantil e moderno dessas práticas, encobrindo de rusticidade relações sociais, econômicas e culturais que, embora tenham contornos específicos, podem ser pensadas, ampliando a escala, como parte de um sistema de relações típicas do processo de acumulação de capital na época moderna, assim como, guardando as devidas proporções, o tráfico negreiro.

O deslocamento das práticas sertanistas para regiões cada vez mais distantes do litoral atlântico ocorria tanto por vias terrestres quanto por vias fluviais. A reprodução destas práticas impulsionou o plantio de roças nas margens dos rios e caminhos de terra. Não é possível precisar quando foram formadas as primeiras espacialidades rurais luso-americanas nestes territórios; o que é certo, seguindo os indícios documentais, é que elas garantiram o abastecimento da empresa sertanista, e, ao mesmo tempo, funcionaram como fonte de lucros pra os roceiros. ${ }^{5}$

Muitas dessas roças, como aponta Jonh Manuel Monteiro, ${ }^{6}$ eram formadas com trabalho dos ameríndios, seja submetidos a regimes de trabalho compulsório, muitas vezes encobertos pela instituição da administração, seja aliados aos colonos, de forma relativamente independente. ${ }^{7} \mathrm{O}$ caráter fronteiriço dessas relações entre colonos e povos ameríndios extrapola o campo das indefinidas fronteiras geopolíticas entre territórios portugueses e espanhóis. Estes ameríndios reproduziam práticas sociais que os inseriam na sociedade colonial em relações

${ }^{4}$ Como por exemplo: expansão da fronteira europeia, interesses econômicos das elites coloniais, produção rural em várias partes da colônia e acumulação de capitais com a prática de captura e venda de escravos indígenas.

5 Como sugere o parecer de Rodrigo César de Meneses ao rei d. João V. Lisboa, 08-01-1732. mss., microfilme, rolo 01, doc. 54 (AHU) - NDIHR/UFMT.

6 MONTEIRO, John Manuel. Negros da terra: índios e bandeirantes nas origens de São Paulo. São Paulo: Companhia das Letras, 1994.

MONTEIRO, John Manuel, op. cit., p. 91. 
de troca com os colonos, com a produção de excedentes, do mesmo modo que em seus territórios reproduziam práticas locais de longuíssima duração.

Para Monteiro "as exigências da economia colonial muitas vezes alteraram a divisão do trabalho a ponto de romper definitivamente os padrões tradicionais da agricultura de subsistência". Ao mesmo tempo em que os ameríndios forneciam aos colonos produtos do seu trabalho, recebiam em troca produtos que modificavam a lógica da produção ameríndia, como as ferramentas de metal, por exemplo. ${ }^{8}$

As relações entre ameríndios e colonos não se davam apenas pelo "escambo", mas também na troca de mercadorias por dinheiro. Estas trocas ocorriam nos pontos de contato entre as sociedades ameríndias e parcelas da sociedade colonial. A repetição das trocas e a consequente regularidade destas transformavam parte da produção em excedente e, por conseguinte, em mercadorias e, concomitantemente, as mercadorias produzidas pela sociedade colonial tornavam-se necessidades entre os povos ameríndios.

A produção agrícola de ameríndios relativamente autônomos, possibilitando a expansão da exploração do trabalho ameríndio de forma compulsória, foi apenas uma das características da colonização portuguesa que demonstram a diversidade das relações mantidas entre colonos e povos ameríndios. Relações que se tornariam ainda mais complexas com o posterior contato com povos como os Kaiapó, Payagoá, e Mbayá-Guaycuru que mantinham, desde o século XVI, relações com os espanhóis.

A relação entre a expansão das conquistas e da colonização portuguesas com os diferentes povos indígenas tem despertado interesse dos historiadores brasileiros das últimas décadas. Além do já citado trabalho de John Manuel Monteiro, outros estudos têm orientado as pesquisas dos historiadores sobre a temática. Embora não proponhamos, neste artigo, uma análise sobre as relações entre ameríndios e colonização portuguesa, é conveniente fazer alguns apontamentos sobre a questão.

John Hemming, no texto "Os índios e a fronteira no Brasil colonial", analisa a expansão da fronteira europeia em relação aos povos indígenas e utiliza, de forma bastante recorrente, as ideias de extermínio e destruição. Em Hemming, de uma forma geral, a relação entre ameríndios e agentes da colonização portuguesa é marcada por uma relação de antinomia, um verdadeiro combate, nos quais os primeiros, embora pudessem alcançar algumas vitórias, estavam fadados

${ }_{8}$ MONTEIRO, John Manuel, op. cit., p. 172. 
à destruição, ao extermínio, ou à fuga. A afirmação sentenciosa de Hemming resume sua intepretação:

No final do período colonial, os poucos índios que viviam sob o domínio português eram criaturas patéticas no extrato mais baixo da sociedade, meio aculturados, despojados da maioria de suas tradições e orgulho tribal, mas totalmente incapazes de adaptar-se aos costumes europeus ou de compreender qualquer dos pontos mais refinados da sociedade europeia. Aquelas tribos que resolveram retirar-se para o interior antes do avanço dos portugueses, para evitar a destruição ou a absorção pelo Brasil português, não eram mais que uma vaga ameaça numa fronteira distante. ${ }^{9}$

Embora criticada por muitos autores, por reduzir a complexidade das ações ameríndias e ofuscar relações de alianças e as estratégias dos diferentes povos frente ao avanço da "fronteira europeia", autores têm reafirmado a concepção de extermínio e destruição para contextos específicos, como Pedro Puntoni, que analisa o conjunto de acontecimentos ocorridos nas capitanias do norte (hoje nordeste) que ficou conhecido como Guerra dos bárbaros. ${ }^{10}$ Para Puntoni, o objetivo seria o extermínio dos ameríndios que ameaçavam a consolidação do processo de colonização. ${ }^{11}$

Por outro lado, em livro lançado um ano após a publicação de $A$ guerra dos bárbaros, Cristina Pompa critica o binômio entre vencedores (portugueses) e vencidos (indígenas) na relação entre agentes da colonização e os Tupinambá e Tapuia e, a partir da análise das práticas de catequização, analisa a forma como as relações de poder engendram resultados que estão longe de ser a simples imposição ou subjugação dos índios a uma sociedade colonial externa a estes. ${ }^{12}$ Mais do que a interpretação particular de um ou outro autor, o debate denota a polarização relativa das correntes analíticas.

9 HEMMING, John. Os índios e a fronteira no Brasil colonial. In BETHELL, Leslie (org.). América Latina colonial. V.II. São Paulo: Edusp/Brasília: Fundação Alexandre de Gusmão, 2008, p. 469.

${ }^{10}$ PUNTONI, Pedro. A guerra dos bárbaros. São Paulo: Fapesp/Hucitec/Edusp, 2002.

${ }^{11}$ PUNTONI, Pedro, op. cit., p. 45.

${ }^{12}$ POMPA, Cristina. Religião como tradução: missionários, Tupi e Tapuiano Brasil colonial. Bauru, SP: Edusc, 2003. Embora a análise de Pompa constitua uma contribuição original, a autora segue os passos de referências importantes, como, por exemplo, Ronaldo Vainfas que, no livro $A$ heresia dos índios, aponta para a reinterpretação da mensagem religiosa dos missionários por parte dos tupis caraíbas tupis. VAINFAS, Ronaldo. A heresia dos índios: catolicismo e rebeldia no Brasil colonial. São Paulo: Companhia das Letras, 1995. Marcio Santos, em tese recém defendida sobre as fronteiras no sertão baiano expõe o confronto entre as interpretações de Pompa e Puntoni. SANTOS, Márcio R. A. dos. Fronteiras do sertão baiano: 1640-1750. Tese de doutorado em História Social. Departamento de História/FFLCH, USP, 2010, p. 115. 
Obviamente que o recorte espacial e temporal de nosso objeto de análise impõe profundas limitações à aplicação de uma ou outra corrente interpretativa. Embora tenha ocorrido guerra justa no ambiente pantaneiro contra os Paiaguá que pode, de forma legítima como propôs Nauk M. de Jesus, aproximar a análise das relações entre colonização portuguesa e presença indígena da interpretação de Puntoni, ${ }^{13}$ existem, como apontou a autora, especificidades da dinâmica da colonização em uma área como as minas de Cuiabá.

Assim sendo, a guerra justa contra os índios Payaguá revela a dinâmica desse espaço de fronteira e a existência de diversos grupos e interesses, representados também pela câmara municipal da Vila Real do Senhor Bom Jesus do Cuiabá. (...) Por outro lado, além da defesa das terras da fronteira oeste e de seus moradores, a contenção dos Payaguá era necessária, porque além de ameaçarem a conquista, (...) prejudicavam os cofres reais e dos moradores que se dirigiam para as minas, pois no saque levavam ouro e escravos, produtos importantes e de grande valia na sociedade escravista colonial recém formada na fronteira oeste. ${ }^{14}$

Apesar da guerra justa, as relações entre agentes coloniais e ameríndios oscilavam entre os limites do confronto que levou à destruição de muitas aldeias e também a reterritorialização dos povos indígenas de várias formas, como no caso dos próprios Payaguá (que mantiveram uma política independente em relação aos domínios hispânicos e portugueses, negociando com os primeiros, atacando os segundos). ${ }^{15} \mathrm{O}$ confronto que marcou a relação entre a colonização portuguesa não apenas com os Payagoá, mas com outros povos ameríndios, com destaque para os Kaiapó e os Mbaya-Guaycurú, não foi a única relação estabelecida entre diferentes lados de uma fronteira que, muitas vezes, olhada mais de perto, era bem mais diluída do que se ousaria supor. Mesmo Hemming, tão firme em sua descrição do extermínio e da destruição, é traído pelos indícios da diversidade das relações, que ele mesmo expõe,

Os campos de ouro do Cuiabá se localizavam no território dos bororos; no entanto embora a maior parte dessa nação fosse hostil aos portugueses, tenderam a evitar o contato. ${ }^{16}$

13 JESUS, Nauk Maria de. A guerra justa contra os Payaguá ( $1^{\mathrm{a}}$ metade século XVIII). Revista Eletrônica História em Reflexão, v. 1, 2007, p. 1-17.

${ }^{14}$ JESUS, Nauk Maria de, op. cit., p. 15.

${ }^{15}$ Ver OLIVEIRA, Tiago Kramer de. Ruralidade na terra da conquista: ambientes rurais lusoamericanos no centro da América do Sul. Dissertação de mestrado em História. Cuiabá, UFMT, 2008, p. 47.

${ }^{16}$ HEMMING, John, op. cit., 462. 
A longa trilha que levava de São Paulo ao campo mineiro de Sant'Anna (Vila Boa de Goiás) estava exposta aos ataques de grupos caiapós do sul (...). Depois do insucesso de várias expedições punitivas, as autoridades recorreram a Antonio Pires de Campos, um paulista que se ligara de amizade a alguns inimigos dos caiapós, os bororos do centro do Mato Grosso. ${ }^{17}$

Embora a comparação entre os dois trechos não possa denotar contradição lógica, já que a utilização das palavras "a maior parte” no primeiro trecho e "alguns" e "do centro do Mato Grosso" no segundo tiram qualquer possibilidade de um raciocínio em forma de silogismo, não há dúvida de que há indícios de que as relações de aliança, as "amizades", faziam sentido não apenas como estratégia de subjugação e extermínio para os agentes da conquista e da colonização, mas também eram tomadas de posição por parte dos ameríndios que, neste texto, dando ênfase à espacialização das práticas de conquista, chamamos de reterritorializações indígenas. Os Bororo, que só seriam desterritorializados definitivamente (após vários conflitos no século XIX, em função do avanço das fazendas de gado em seus territórios) pela sociedade não-índia, no início do século XX, ocupavam tanto regiões do Cerrado, quanto do Pantanal, entre o rio São Lourenço e Cuiabá, ficando, portanto, a vila de Cuiabá, em meio aos territórios "oriental" e "ocidental" dos Bororo. ${ }^{18}$ A "tendência" percebida por Hemming para o princípio da colonização de "evitar o contato" no primeiro trecho citado e a "ligação de amizade" no segundo podem ser analisadas se conjecturarmos um ponto de vista para os ameríndios como tática de defesa, visando à reprodução de práticas sociais seculares e manutenção, mesmo parcial, de seus territórios e ainda pode ser interpretada como estratégia de ataque aos inimigos seculares, aliando-se aos sertanistas.

As considerações acima feitas não expõem a complexidade das relações entre ameríndios e as conquistas portuguesas. O que expomos, contudo, é a existência de uma diversidade de possibilidades engendradas em decorrência da reprodução de práticas sertanistas, por um lado, e pela especificidade de um território de mineração e fronteira, por outro. ${ }^{19}$

${ }^{17}$ HEMMING, John, op. cit., 461 (grifo meu).

${ }^{18}$ VIERTLER, Renate Brigitte. As duras penas: um histórico das relações entre índios Bororo e “civilizados” no Mato Grosso. São Paulo: FFLCH-USP, 1990.

${ }^{19}$ Para um estudo sobre a diversidade de relações estabelecidas entre ameríndios e a expansão da colonização portuguesa, ver a análise pormenorizada e riquíssima de Thereza Martha Presotti que problematiza os relatos sobre a natureza e os índios no contexto da colonização de Cuiabá e de Mato Grosso na primeira metade do século XVIII, e aponta tanto as estratégias dos conquistadores quanto se aprofunda na percepção do modo de vida e os costumes de diversos povos ameríndios. PRESOTTI, Thereza Martha. Na trilha das águas: Índios e natureza na conquista 
Sem prejuízo às contribuições mais recentes, e tendo em vista a escala de análise e o objeto de estudo que nos propomos a discutir, a análise de John Manuel Monteiro, que destaca a escravização indígena como fundamento da expansão sertanista (embora sempre visasse a procura por metais preciosos), é mais adequada para tratarmos do avanço das conquistas portuguesas aos territórios ameríndios. Contudo, os descobertos de ouro reorientariam as práticas sertanistas, articulando estas práticas à mineração, ao comércio e à produção agrária.

Portanto, mesmo considerando, como aponta Monteiro, que práticas coloniais espacializavam-se nos interiores da América do Sul, possibilitando a captura e tráfico de negros da terra e a procura e exploração de metais preciosos, é somente após a descoberta de significativos veios auríferos nas regiões próximas ao rio Cuiabá que se espacializaram, de forma estável e interligada, ambientes coloniais fixos.

\section{A paisagem do Pantanal e a imagem da ruralidade nas minas de Cuiabá}

Antes da exploração aurífera de forma sistemática, já se reproduziam, ainda que de forma embrionária, atividades produtivas que visavam o abastecimento. Quando se inicia a exploração de forma ordenada nas minas do rio Coxipó-Mirim, em 1718, percebe-se, por meio da documentação que, simultaneamente à atividade mineradora, expandem-se atividades agrícolas. ${ }^{20}$ Mesmo que os indícios apontem para formação de ambientes rurais fixos desde pelo menos 1718, muitos autores construíram suas análises tendo como pressuposto o caráter improvisado e inconstante dos ambientes rurais.

Poderíamos apenas citar fatores que contraponham essa interpretação denotando o equívoco desses pressupostos. Todavia, talvez menos por necessidade para a construção de nosso objeto e mais por compromisso com a historicidade do discurso histórico, faremos algumas considerações sobre a presença da ausência de ambientes rurais em obras de historiadores (ou textos de cunho histórico de forma geral).

Em artigo intitulado "Historiadores e cronistas e a paisagem da colônia Brasil", Dora C. Shellard afirma que uma das imagens que orienta o trabalho dos historiadores com a documentação é a imagem de uma "natureza virgem, de terras desabitadas, vazias da ação humana no Brasil de outrora" e acrescenta que

colonial do centro da América do Sul, sertões e minas do Cuiabá e Mato Grosso, século XVIII (1718-1752). Tese de doutorado em História, UnB, 2008.

${ }^{20}$ SÁ, José Barboza de. Relação das povoações do Cuiabá e Mato Groso de seus princípios até os presentes tempos. Cuiabá: Ed. UFMT/Secretária de Educação e Cultura, 1975, p. 11. 
"embora muitos já tenham criticado essa visão e apontado o descaso para com as populações indígenas, ela não foi superada. O discurso crítico foi ineficaz na substituição desse cenário por outro mais próximo do real". A autora nomeia os modeladores desta paisagem, afirmando que "ainda nos pautamos sem remendos em Caio Prado Júnior ou em Capistrano de Abreu, criadores desse modelo de descrição da paisagem do Brasil colonial, para descrever o processo de avanço da ocupação portuguesa. ${ }^{21}$ Destacamos um aspecto da crítica de Shellard, particularmente significativo para nossa análise,

Capistrano de Abreu e Caio Prado Júnior utilizam predominantemente fonte do século XIX. (...) Além disso, estes viajantes de onde os historiadores recuperam a paisagem colonial, por questões metodológicas que se impõem até hoje, separavam a descrição da natureza das formas de ocupação humana. ${ }^{22}$

Será possível estender as observações que Dora Shellard faz sobre o silêncio em relação à presença indígena na paisagem colonial ao silêncio em relação à presença de ambientes rurais nas minas do Cuiabá na primeira metade do século XVIII, em particular no Pantanal? A análise de Shellard é inspiradora em muitos aspectos, ${ }^{23} \mathrm{em}$ particular na percepção sobre a relação entre as categorias de tempo e espaço operacionalizadas nos escritos do século XIX e sua marca na produção histórica, inclusive na mais contemporânea. Distanciamos-nos, contudo, da análise da autora quando esta atribuiu a Capistrano de Abreu e a Caio Prado Junior a criação do que a autora chama de "modelo de descrição". Ao menos no caso do silêncio em torno da existência e da importância de ambientes rurais em Mato Grosso, não procuraremos autores que criaram "um modelo", mas representações que se cristalizaram e foram ressignificadas por diversos autores.

Não empreendemos uma busca incessante "pelas raízes" da ausência da ruralidade nos discursos. Podemos, contudo, a partir da leitura de referências bibliográficas e da documentação, encontrar, em meados do século XIX, uma imagem que abriga muitas das representações existentes nas interpretações ulteriores.

${ }^{21}$ SHELLARD, Dora Corrêa. Historiadores e cronistas e a paisagem da colônia Brasil. In: Revista Brasileira de História, v. 26, n 51, 2006, p. 63-97, p. 64.

${ }^{22}$ SHELLARD, Dora Corrêa, op. cit., p. 69.

${ }^{23}$ Como quando afirma que "este esforço justifica-se pragmaticamente, pois são essas concepções equivocadas sobre a realidade paisagística brasileira pretérita que povoam o imaginário de muitos que têm tomado decisões quanto às políticas relacionadas ao meio ambiente, ao índio e a questão da terra". SHELLARD, Dora Corrêa. Historiadores e cronistas e a paisagem da colônia Brasil, op. cit., p. 66. 
Destacamos os Anais de Mato Grosso, de Henrique Beaurepaire-Rohan, ${ }^{24}$ escrito em meados do século XIX. Tendo como base relatos de cronistas e documentos do Conselho Ultramarino, este autor afirma que "era tal o afã com que os primeiros colonos se entregavam aos trabalhos nas lavras, que nem sequer tratavam de prover aos meios de subsistência", e acrescenta que "a lavoura desprezada e as poucas plantações que haviam pereciam já por falta de trato, já pelo rigor das estações. Nem lançaram mão da pesca, sendo aliás tão piscoso o rio". ${ }^{25}$

Em 1843, Henrique de Beaurepaire-Rohan, então jovem engenheiro militar de trinta e um anos, "foi designado para servir na comissão militar para a exploração e levantamento do baixo Paraguai, quando teve a oportunidade de conhecer Mato Grosso e onde permaneceu por quase três anos" e teve, segundo Costa e Silva, uma relação próxima com Augusto João Manuel Leverger, ${ }^{26}$ chegando justamente no mesmo ano em que o último aceitou o cargo de cônsul para tratar de assuntos de fronteira e sobre a navegação do rio Paraguai, assunto que se tornaria obstinação para Leverger e outros membros da elite política e econômica de Mato Grosso. Mas a ausência de rotas de navegação que pudessem escoar a produção não era o único entrave apontado. Ao que nos interessa particularmente neste artigo, tanto a população indígena como livres pobres eram vistos como empecilho para o desenvolvimento.

Em recente e importante contribuição, Ana Carolina da Silva Borges mostra que a nova concepção de trabalho criada no contexto europeu e que circulava no discurso de viajantes e autoridades (e embasava atitudes, políticas, leis) desqualificava as práticas rurais reproduzidas pelos agricultores pobres do Pantanal, não vistas como trabalho, pois não geravam lucro que pudesse ser reinvestido na produção nem excedente que pudesse ser comercializado externamente e assim produzir riqueza para a província, além do fato de terras que poderiam gerar riqueza não estarem sendo exploradas racionalmente. ${ }^{27}$ Apesar de Borges centrar sua análise no período posterior a 1870, é evidente, nos relatórios e discursos dos presidentes de província, desde pelo menos a década de 1840, que esta concepção

${ }^{24}$ BEAUREPAIRE-ROHAN, Henrique. Anais de Mato Grosso. Publicações avulsas n 20 . Cuiabá: IHGMT, 2001.

${ }^{25}$ BEAUREPAIRE-ROHAN, Henrique, op. cit., p. 17.

${ }^{26}$ COSTA E SILVA, Paulo Pitaluga. Apresentação. In: BEAUREPAIRE-ROHAN, Henrique de. Anais de Mato Grosso. Cuiabá: IHGMT, Publicações avulsas, n 20, 2001, p. 7. Augusto João Manuel Leverger tornar-se-ia presidente de província de Mato Grosso por vários mandatos, herói na Guerra do Paraguai e barão de Melgaço.

${ }^{27}$ BORGES, Ana Carolina da S. Nas margens da história: meio ambiente e ruralidade em comunidades "ribeirinhas" do Pantanal Norte (1870-1930). Cuiabá: Carlini Caniato/Edufmt, 2010. 
servia aos mandatários locais para justificar práticas de invasão dos territórios indígenas e criticarem as práticas rurais, deslegitimando o acesso dos ribeirinhos à terra, e justificando, por exemplo, a necessidade de colonização estrangeira.

Não nos parece que Beaurepaire-Rohan ficaria isento destes valores que depreciavam as práticas rurais de forma generalizada. A falta de racionalidade na exploração dos recursos naturais, o "desprezo pela lavoura", a "falta de trato", ou seja, de trabalho, apontados pelo autor dos Anais, correspondem mais aos problemas que surgiam no enquadramento de Mato Grosso ao idealismo do progresso do que de sua análise da documentação do período colonial.

Tal concepção tornar-se-ia ainda mais perceptível com a intensificação das relações entre Mato Grosso e outras províncias e países graças à reabertura, em 1870, da navegação com a bacia do Prata e a utilização do barco a vapor. Lilya da S. G. Galleti assim resumiu a forma como o espaço mato-grossense foi configurado pela literatura de viagens de meados do XIX e início do XX:

um lugar longínquo, perdido no tempo e no espaço. Um território gigantesco, a desafiar uma população diminuta, composta por uma maioria de mestiços e indolentes, cujos hábitos e atitudes os colocavam nos limites da barbárie, e de um expressivo contingente de selvagens, vivendo ainda na infância da humanidade, um depósito de riquezas naturais abundantes e inesgotáveis que prometiam um futuro fabuloso tão logo pudessem ser exploradas pelas maravilhas da técnica, do capital e do trabalho disciplinado oriundos do mundo europeu. ${ }^{28}$

Não podemos perder de vista, a própria Galleti aponta, que a percepção de um espaço vazio e não explorado fomentou muitas políticas públicas ulteriores em relação ao território mato-grossense ${ }^{29}$ como exemplo, podemos citar a Marcha para o Oeste (no governo Vargas) e o Projeto de Integração Nacional (PIN), durante a ditadura militar.

No princípio do século XX, com o crescimento econômico e de importância política do estado de São Paulo no contexto nacional, a construção do "mito do bandeirante" e da "raça de gigantes" tinha, na expansão territorial atribuída aos paulistas, um de seus aspectos centrais. ${ }^{30}$ Segundo Raquel Gekzer houve "a transposição do bandeirante do século XVII para o paulista do século XX, dando sentido de continuidade e qualidade aos habitantes do Estado", ou seja, "da mesma

${ }^{28}$ GALETTI, Lylia da S. G. O poder das imagens: o lugar de Mato Grosso no mapa da civilização. In: UNIVERSIDADE FEDERAL DE GOIÁS- UFG (org.). Relações cidades-campo. Goiania: EdUFG, 2000, v. 1, p. 21-52.

${ }^{29}$ GALETTI, Lylia da S. G., op. cit., p. 52.

${ }^{30}$ SCHWARCZ, Lilia M. O espetáculo das raças. Cientistas, instituições e questão racial no Brasil (1870-1930), p. 126-133. 
forma que o bandeirante desbravara os sertões brasileiros conquistando-os para Portugal e criando o Brasil geograficamente, o paulista, isto é, o Estado de São Paulo, melhor dizendo, a oligarquia paulista, construía o progresso do Brasil". ${ }^{31}$

No que diz respeito à formação de ambientes rurais nas áreas de conquista e do "desbravamento dos sertões", em particular nas minas do Cuiabá, à imagem construída no século XIX se superpuseram outras representações, em particular, a da ação do bandeirante neste território. Visto como o agente único responsável pela expansão territorial, suas características principais eram "aventureiro, no bom sentido do termo, audacioso e corajoso". ${ }^{32}$ Estas características não "compactuariam" com o desenvolvimento de uma agricultura nas áreas de expansão das atividades sertanistas. Como afirmou um dos principais autores paulistas deste período, Washington Luís, "a agricultura, tarda na retribuição ao trabalho, não se compactua com o desejo febril de enriquecer rapidamente; definhava, estiolavase, e recebia golpe de morte com a descoberta das minas de ouro". ${ }^{33}$

A valorização do passado bandeirante não foi exclusividade dos paulistas. Em Mato Grosso, os membros do IHGMT, exaltavam os heróis da colonização e, ufanistas, construíram a imagem de um período de fausto e uma "idade de ouro" no princípio da colonização. Em Mato Grosso, as representações sobre o isolamento e bandeirantismo assumiam o caráter das disputas de poder entre os nortistas (a elite de Cuiabá e municípios próximos) e os sulistas (do atual Mato Grosso do Sul). Segundo Galetti, os intelectuais nortistas conferem "aos descendentes das famílias mais antigas e tradicionais (...) um atávico pelo progresso, o mesmo que havia feito de São Paulo a 'locomotiva do Brasil' distingue-os como os verdadeiros faróis da civilização, no grande sertão do Oeste brasileiro". ${ }^{4}$

Entre os membros do IHGMT, destacamos Virgílio Corrêa Filho (que também era membro do IHGB). O autor escreveu uma imensa quantidade de textos e foi pioneiro em vários temas da produção histórica de Mato Grosso, inclusive sobre a história e a geografia do Pantanal. No livro Os pantanais matogrossenses, Corrêa Filho destaca a atividade da pecuária no século XVIII,

Se, já pelo século XVIII, a pecuária cuiabana excedia as solicitações do mercado regional, daí por diante, à medida que esmoreciam as minas de ouro, pelo esgotamento das aluviões

${ }^{31}$ GLEZER, Raquel apud BLAJ, Ilana. Na trama das tensões: o processo de mercatilização de São Paulo colonial. São Paulo: Humanitas/Fapesp, 2002, p. 53-54.

${ }^{32}$ Imagem que se projetava também à elite paulista do início do período republicano. BLAJ, Ilana, op. cit., p. 48.

${ }^{33}$ LUIS, Washington. Capitania de São Paulo. Governo de Rodrigo César de Meneses. $2^{\mathrm{a}}$ edição. Rio de Janeiro/São Paulo/Recife/Porto Alegre: Companhia Editora Nacional, 1938, p. 22.

${ }^{34}$ GALETTI, Lylia da S. G., op. cit., p. 50. 
empiricamente lavradas, maiores esforços desviados da mineração evanescente iriam aplicar-se na lavoura e criação de gado, ainda que escasseassem consumidores. ${ }^{35}$

Vemos que a relação estabelecida entre mineração e o setor agrário é a mesma em Corrêa Filho e em Washington Luis, ou seja, a abundância do ouro impede o desenvolvimento da agricultura. Apenas quando há decadência da mineração, o que segundo Corrêa Filho ocorre rapidamente, se aplicariam "esforços" em desenvolver a agricultura e a pecuária.

A respeito da criação de gado no Pantanal, Corrêa Filho destaca a "seleção natural" que formara "uma variedade bovina pantaneira". ${ }^{36}$ Assim como o Pantanal fora responsável pela criação do "boi pantaneiro", o mesmo transformou o Pantanal. Uma relação de adaptabilidade mútua entre o gado e o ambiente. ${ }^{37}$

A contribuição de Corrêa Filho para uma história social dos ambientes rurais é muito significativa. O autor apontou uma diversidade de agentes sociais e descreveu ricamente as paisagens pantaneiras. Todavia, faremos três apontamentos sobre o Pantanal de Corrêa Filho, a saber: o primeiro, a harmonia dos grupos sociais entre si (mesmo na inserção do índio no trabalho, o conflito é minimizado em favor do destaque à sua aptidão ao trabalho pastoril) ${ }^{38}$ o segundo, a harmonia com o ambiente natural - assim como o gado, também as pessoas aparecem na obra de Corrêa Filho como adaptadas aos ritmos do Pantanal, como parte do ambiente, ou na forma denominada pelo autor como "aspectos humanos". Corrêa Filho, criou, ao seu modo, a imagem do "ribeirinho" do Pantanal, homem "modesto" que vive de forma relativamente independente das grandes fazendas.

${ }^{35}$ CORRÊA FILHO, Virgílio. Pantanais matogrossenses. Devassamento e ocupação. Rio de Janeiro: IBGE, 1946, p. 102.

${ }^{36}$ CORREA FILHO, V. Mato Grosso. Rio de Janeiro: IHGB, p. 197.

37 "O gado, porém, à procura de água e pastagem, experimentava cautelosamente, passo a passo, em suas contínuas avançadas, a consistência do terreno, que aos poucos se consolidou pela espremedura a que submeteram milhares de cascos. E na atualidade, cursos d'água, de que não podiam aproximar-se os viajantes, (...), já permitam a travessia em condições favoráveis, iniciada pelos bovinos. As suas patas incumbiram-se de transformar a lama em camada coesa, que suporta pesos, outrora incompatíveis, por demasiados, com a minguada resistência. E assim transforma-se progressivamente, o Pantanal". CORREAA FILHO, Virgílio. Fazendas de gado no Pantanal matogrossense. Rio de Janeiro: Ministério da Agricultura, 1955, p. 10-11.

${ }^{38}$ Segundo Corrêa Filho, o indígena "revelou-se afeiçoado às tarefas pastorícias, que não lhe contrariavam o gosto inato de contínuas excursões, em que se estadeava qualidades admiráveis para o cabal desempenho de seus encargos (...) equivalente perícia revelava nos trabalhos curraleiros, de leitação e amansamento de animais, no manejo da enxada e machado".(...) "bororo do São Lourenço ou do Paraguai, guató (...) todas as tribos revelavam análogas aptidões, que facilitaram a expansão pastoril pelos campos outrora por elas senhoreados". CORRÊA FILHO, V. Pantanais matogrossenses, op. cit., p. 123-124. 
A imagem, como o nome sugere, constrói uma relação de imbricação do homem com o rio. Em suas descrições, Corrêa Filho circunscreve o campo de ação dos ribeirinhos ao rio e às suas margens; por fim, a centralidade das grandes fazendas de gado na paisagem pantaneira.

A questão da centralidade do latifúndio pastoril remete-nos à análise da interpretação de um autor que, muito embora seja pouco citado, traz em suas obras enunciados presentes (de forma explícita ou tácita) em estudos de vários outros autores e em discursos não acadêmicos. Oliveira Viana, na obra Populações meridionais do Brasil, construiu uma interpretação que buscava dar conta de aspectos sociais, políticos, econômicos, psicológicos, culturais. As influências de teorias raciais, da antropologia e da psicologia social nortearam a visão de Oliveira Viana sobre o "mundo sertanejo". Viana acoplou ao conjunto de representações existentes no século XIX uma teoria racial bastante em voga. Para Viana "na sociedade colonial, o desejo de enriquecer, de ascender, de melhorar, de gozar os finos prazeres da civilização só pode realmente existir no homem de raça branca". Quanto ao negro e o índio "na sua generalidade, não sentem, senão excepcionalmente, nos seus exemplares mais elevados, a vontade de alcançar essas situações sociais". ${ }^{39}$

O ponto nevrálgico da tese de Viana é a compreensão de que o latifúndio, em torno do qual o restante da sociedade gravita, é responsável pela simplificação das relações sociais e entrave ao desenvolvimento humano, a civilidade e a solidariedade. $O$ fato de partir de tal caracterização não impediu que o autor visualizasse grupos sociais que se reproduziam de forma mais ou menos independente dos grandes domínios. As relações que estes grupos e os latifundiários estabeleciam foram assim definidas por Viana: “entre essa classe (proletariado do campo) e a aristocracia senhorial, as relações de interdependência e solidariedade não têm nem permanência, nem estabilidade. São frágeis e frouxas. Não se constituem solidamente" ${ }^{40}$

Mesmo visualizando este grupo, ou "classe" como prefere o autor, sua imagem é opaca, escondida entre concepções teóricas pragmáticas e conceitos raciais. Por mais "antiquadas" que possam parecer as formulações de Viana diante do momento atual, não apenas em relação à historiografia, mas às ciências de uma forma geral, suas marcas estão presentes no discurso de muitos historiadores, muitas vezes de forma não consciente. Não é difícil identificar que muitos autores tomam como pressuposto a inexistência de relações sociais regulares, de racionalidade na produção, de organização do trabalho, de vinculação regular

\footnotetext{
${ }^{39}$ OLIVEIRA VIANA, Francisco José. Populações meridionais do Brasil. In: SANTIAGO, Silvio (org.). Intérpretes do Brasil. Rio de Janeiro: Nova Aguilar, 2000, p. 1.011.

${ }^{40}$ OLIVEIRA VIANA, Francisco José, op. cit., p. 1.023.
} 
ao mercado, reproduzindo, com eufemismos, a afirmação de Oliveira Viana de que "nos três primeiros séculos, todos os documentos e testemunhas atestam a desocupação, a ociosidade e a vagabundagem do baixo povo rural". ${ }^{41}$

Em meados do século XX, o historiador paulista Sergio Buarque de Holanda escreverá duas obras primas da historiografia brasileira que tratam da conquista e da colonização "dos sertões" da capitania de São Paulo, os livros Monções e Caminhos e fronteiras. Tanto Dora Shellard, no que diz respeito à construção da paisagem do Brasil colonial, quanto Ilana Blaj, sobre a construção das imagens da capitania de São Paulo, encontraram em Holanda um ponto de inflexão. Shellard lamenta, "ignoramos os passos iniciados por Sérgio Buarque de Holanda, o qual, desde a edição de Monções (1945), apresenta um cenário diverso, uma outra visão de fronteira". ${ }^{42}$ Para Blaj, Holanda rompe com a percepção linear e evolutiva do passado colonial paulista, ao invés de defender a superioridade do branco. Holanda chama atenção para a importância do saber indígena e da incorporação deste saber pelo paulista. A expansão territorial deixa de ser percebida como inata aos paulistas, e passa a ser vinculada aos aspectos da vida material e à necessidade de um "equilíbrio vital". ${ }^{43}$

São conhecidas as afirmações de Buarque de Holanda sobre a inexistência de produção regular de gêneros alimentícios na região das minas do Cuiabá. No entanto, o que nos interessa destacar é como o autor caracteriza a vida rural nos "sertões". De acordo com Holanda,

Em nenhum caso parece lícito dizer que as ferramentas chegaram a alterar de modo substancial os usos da terra. Em realidade, o sistema de lavoura dos índios revela, quase sempre, singular perseverança assegurando-se vitória plena, a ponto de ser adotado pelos adventícios. Os quais, após a primeira geração na colônia, pareciam não raro ignorantes nos hábitos de seus ancestrais, ao contrário da raça subjugada, que se mostrou de um conservantismo a toda prova. ${ }^{44}$

Para o autor, há uma ruptura completa entre a vida rural europeia e a americana, uma subversão da colonização, os hábitos dos colonizados se impondo diante dos colonizadores. Algo que só é possível pela característica específica da colonização dos "sertões". O sertão reproduzido por Holanda exerce sobre

${ }^{41}$ OLIVEIRA VIANA, Francisco José. op. cit., p. 1.062.

${ }^{42}$ SHELLARD, Dora, op. cit., p. 67.

${ }^{43}$ BLAJ, Ilana, op. cit., p. 69-72.

${ }^{44}$ HOLANDA, Sérgio Buarque de. Caminhos e fronteiras. $2^{\mathrm{a}}$ edição. Rio de Janeiro: J. Olympio, 1975, p. 168. 
os corpos uma ação antidisciplinadora, impõe um modo de vida improvisado, inconstante, em que atividades que exigem sedentarismo e regularidade, como a agricultura, não exercem papel importante, não explicam as características da sociedade. O que fornece identidade a esta população de "nômades", "aventureiros" é a mineração que, supostamente, é uma atividade caracterizada pela inconstância, pela mobilidade e pela irracionalidade. Holanda afirma que "os benefícios mais seguros, embora também mais trabalhosos da lavoura, foram logo abandonados pelos do reluzente metal das minas". ${ }^{45} \mathrm{O}$ autor chega a dizer que "os primeiros moradores do arraial cuiabano tiveram uma existência comparável à dos índios coletores e caçadores, existência que só se concilia com um modo de vida andejo e inconstante". ${ }^{46}$

Mais uma vez não são os indícios documentais, embora Sérgio Buarque de Holanda cite vários documentos, que permitem chegar a estas conclusões, mas teorizações que se impõem aos documentos. A imagem de sertão é reveladora de pressupostos que extrapolam a análise documental, imagem que parece inquebrantável, e ainda hoje naturalizada na produção historiográfica do litoral.

De qualquer forma, embora a sua visão em relação à ruralidade nas minas do Cuiabá não apontasse para mudanças significativas, os temas tratados por Sérgio Buarque de Holanda abriram caminho para uma percepção mais complexa sobre a relação entre os paulistas e a conquista das minas do Cuiabá do que a visão reproduzida pelo IHGSP.

Assim como Shellard, Blaj afirma que "poucos autores trilharam os caminhos abertos" por Holanda, segundo a autora "devido às discussões candentes acerca do subdesenvolvimento brasileiro, às práticas sociopolíticas encetadas pelo nacional-desenvolvimentismo e ao primado da sociologia e da história econômica". ${ }^{47}$ De fato, o contexto político e econômico das décadas seguintes orientou os trabalhos dos pesquisadores, no sentido de compreender as raízes do "subdesenvolvimento", do "atraso" e dos "entraves" ao progresso do país.

Em termos de historiografia econômica, dois dos principais autores brasileiros, Caio Prado Júnior e Celso Furtado, ambicionaram construir uma visão de conjunto da história do Brasil. Em Formação do Brasil contemporâneo: Colônia, Caio Prado Júnior, apontou características gerais da história colonial do Brasil. Para o autor, o "sentido da colonização" está na vinculação ao capitalismo co-

\footnotetext{
${ }^{45}$ HOLANDA, Sérgio Buarque de, op. cit., p. 138.

${ }^{46}$ HOLANDA, Sérgio Buarque de, op. cit., p. 149.

${ }^{47}$ BLAJ, Ilana, op. cit., p. 72.
} 
mercial europeu. ${ }^{48}$ Para Prado Júnior as atividades econômicas que explicam o sentido são aquelas assentadas no latifúndio e na escravidão, base da estrutura social da colônia. Nas áreas de mineração, as minas substituíam as lavouras açucareiras, mas a base de exploração do trabalho era a mesma. ${ }^{49}$

Prado Júnior não ignorou a existência de produção rural fora dos grandes domínios. No entanto, para o autor, essas atividades nunca constituíram parte relevante da formação da economia colonial. O que importa para Prado Júnior são as atividades voltadas para o mercado externo, as demais são espasmódicas em relação à principal, "trata-se de atividades subsidiárias destinadas a amparar e tornar possível a realização das primeiras", acrescenta "Não têm vida própria, autônoma, mas acompanham aquelas, a que se agregam como simples dependência", e ratifica "Numa palavra, não caracterizam a economia colonial brasileira, e lhe servem apenas de acessórios". ${ }^{50}$

Não apenas do ponto de vista econômico, a "agricultura de subsistência", principalmente a praticada por livres pobres, é posta à margem da sociedade colonial, mas também do ponto de vista "moral", estes foram inferiorizados a partir de critérios "raciais" e étnicos. Neste ponto, a análise de Caio Prado Júnior tem uma inquestionável e fundamental influência (não explicitada pelo autor) de Oliveira Viana. ${ }^{51}$

Para Furtado, a exploração das minas foi efêmera e a organização social não se tornou complexa o suficiente para a manutenção de uma economia ativa. $\mathrm{O}$ baixo progresso técnico e mental dos colonizadores do sertão são as grandes causas de sua involução. ${ }^{52}$ Embora utilizando a concepção weberiana de racionalidade, é notório, na citação acima, o alinhamento com a tese de Viana em relação à involução da sociedade (e outros aspectos que destacamos deste autor) e também com Sérgio Buarque de Holanda, no que tange às características da agricultura.

${ }_{48}$ PRADO JÚNIOR, Caio. Formação do Brasil contemporâneo - Colônia. São Paulo: Brasiliense, 1997, p. 31.

49 PRADO JÚNIOR, Caio, op. cit., p. 123.

${ }^{50}$ PRADO JÚNIOR, Caio, op. cit., p. 124.

51 "A mediocridade desta mesquinha agricultura de subsistência que praticam, e que nas condições econômicas da colônia não podia ter senão este papel secundário e de nível extremamente baixo, leva para elas, por uma espontânea seleção social, econômica e moral, as categoria inferiores da colonização. Não encontramos aí, por via de regra, senão um elemento humano, residual, sobretudo mestiços do índio que conservaram dele a indolência e qualidades negativas para um teor de vida material e moral mais elevado. Ou então, brancos degenerados e decadentes". PRADO JÚNIOR, Caio, op. cit., 161.

${ }^{52}$ FURTADO, Celso. Formação econômica do Brasil. 32ª edição. São Paulo: Companhia Editora Nacional, 2003, p. 91. 
Obviamente que das primeiras décadas do século XX até dias hodiernos, as imagens construídas sobre as minas do Cuiabá e a paisagem do Pantanal modificaram-se. Contudo, em que pesem as diferenças entre as abordagens dos autores, em alguns pontos absolutamente contrárias umas às outras, a imagem construída sobre os ambientes rurais não é divergente. ${ }^{53}$ Tais imagens, porém, não se circunscrevem aos trabalhos acadêmicos. Muito ao contrário, as representações que constroem estas imagens são apropriadas pelos mais diversos agentes sociais, e ressignificadas, de acordo com seus interesses.

Atualmente, são marcantes nos discursos sobre o Pantanal os interesses do ecoturismo promovido por grandes entidades que se utilizam de uma imagem de natureza intocada ${ }^{54}$ do ambiente Pantanal e que promovem a pesca esportiva, onde o homem pantaneiro, idealizado e descontextualizado, é mais uma entre as atrações para os turistas. Concomitantemente, há outro movimento de revalorização das grandes fazendas de gado "tradicionais" (com a reprodução da imagem da simbiose entre gado/ Pantanal/homem pantaneiro) pelo discurso atual de manejo sustentável dos grandes rebanhos.

As práticas discursivas e não-discursivas que estas representações impulsionam atualmente merecem estudos a parte. É possível afirmar, contudo, que os discursos que manipulam a história a serviço da memória, e a produção de silêncios têm impulsionado práticas excludentes em relação aos agricultores pobres que compuseram a paisagem do Pantanal muito além das margens dos rios, desde sua colonização, e que hoje são impedidos, por diversos fatores, de reproduzir práticas sociais, culturais e econômicas, que inclusive permitiram, ao longo dos séculos, a reprodução do ambiente conhecido como Pantanal.

\section{Fendas no silêncio: ruralidade nas minas do Cuiabá e a emergência do Pantanal}

Os indícios documentais permitem-nos reconstruir uma paisagem diversa daquela cristalizada pela historiografia e pela memória. A análise sobre a ruralidade

\footnotetext{
${ }^{53}$ Uma análise divergente que merece ser destacada e aborda a relação entre produção aurífera e agricultura, apontando a existência de um setor agropastoril vinculado ao mercado interno, foi elaborada por Elmar Arruda. Segundo o autor "a agricultura é cultivada desde os primeiros anos de exploração do ouro, em pequena escala, mas sempre aumentando o número de plantações. (...) Assim houve a formação de um pequeno complexo econômico. Não (...) um pujante mercado, mas sim um mercado" ARRUDA, Elmar Figueiredo. O mercado interno de Mato Grosso - século XVIII. Brasília: Gráfica do Senado Federal, 1991, p. 95.

${ }^{54}$ Sobre esta questão ver DIEGUES, Antonio Carlos. O mito moderno da natureza intocada. São Paulo: Hucitec, 1998.
} 
nas minas do Cuiabá no século XVIII possibilita a desconstrução de elementos formadores de uma paisagem idílica do Pantanal do século XX e XXI.

Nos mesmos documentos que autores anteriormente citados utilizaram encontramos indícios para contrapor suas afirmações. Seguindo a crônica de Barbosa de Sá, por exemplo, percebemos que, concomitantemente aos descobertos, os sertanistas "trataram logo de fabricar casas e lavouras pelas margens dos rios Cuiabá e Coxipó, extinguindo uma aldeia de gentio que se achava no lugar chamado hoje porto do Borralho". ${ }^{55}$ Ocorreram, a partir de então, vários outros descobertos, o principal deles no córrego Prainha, afluente do rio Cuiabá.

No mês de outubro deste ano (1722) fez Miguel Sutil, natural de Sorocaba viagem pra uma roça que tinha principiado na borda do Cuiabá. Lugar onde depois foi sítio de Manoel dos Santos Ferreira; chegando plantou o seu roçado e mandou dois carijós ao mel (....). ${ }^{56}$

Analisando este trecho da narrativa percebemos indícios da expansão de atividades rurais ao longo das margens do rio Cuiabá e a exploração de atividades complementares como a extração de mel. ${ }^{57}$ Do local onde se formaram as roças, nos descobertos do Coxipó, até o córrego do Prainha, levava-se por volta de 18 a 20 dias de viagem pelo rio Cuiabá. ${ }^{58}$

Além do relato de Barbosa de Sá, as cartas de sesmarias também fornecem indícios sobre a formação de ambientes rurais nos primeiros anos de conquista portuguesa no centro da América do Sul. Em muitas das cartas de sesmarias, concedidas a partir de 1726 , as autoridades foram informadas que os requerentes já ocupavam as terras há alguns anos além de citar vizinhos, não requerentes, que também possuíam roças e criações. ${ }^{59}$ A relação das sesmarias concedidas por Rodrigo César de Meneses possibilita a percepção dos locais onde espacializavam-se as atividades rurais. No quadro de que dispomos, citado por

${ }_{55}^{5}$ SÁ, José Barboza de, op. cit., p. 11. Apesar de evidente nas citações, nunca é demais lembrar que a colonização foi um processo de desterritorialização de milhares de ameríndios para a formação de uma minúscula sociedade colonial portuguesa no centro da América do Sul.

${ }^{56}$ SÁ, José Barboza de, op. cit., p. 14.

${ }^{57}$ Nos documentos percebemos que o mel era ingrediente de vários remédios e bebidas.

${ }^{58}$ Auto Sumário. Vila Real do Senhor Bom Jesus do Cuiabá, 12-04-1736; mss., microfilme, rolo 01, doc. 84 (AHU) - NDIHR/UFMT.

${ }^{59}$ Por exemplo, o pedido de Ângelo da Fonseca Leitão que, ao requisitar sesmarias na margem do rio Cuiabá, em 1726, argumenta que é morador do lugar há seis anos e cita dois vizinhos, Paulo da Costa e Bento do Rego como "antigos moradores". Carta de sesmarias concedida a Ângelo da Fonseca Leitão; Cuiabá, 08-01-1727; AESP-Sesmarias-1720/1736 - v. III. São Paulo, 1937 apud SIQUEIRA, Elizabeth Madureira. A ocupação pioneira da região do rio Cuiabá abaixo. Cuiabá: IHGMT. Publicações Avulsas, nº 1, 1997, p. 12-14. 
Canavarros, ${ }^{60}$ não há uma localização precisa, mas das 38 concessões, oito $(21 \%)$ são claramente em áreas do Pantanal, ou seja entre os rios Taquari e Cuiabá abaixo. É necessário apontar que as cartas de sesmarias são apenas indícios da presença de espacialidades rurais, uma vez que grande parte delas era requerida anos depois da efetiva presença dos requerentes e também que muitas terras não eram requisitadas por sesmarias, o que fica bastante evidente nas próprias cartas que citam limites com confinantes que não possuíam a posse da terra legitimada por doação de sesmarias.

Por meio das cartas percebemos que as unidades produtivas multiplicaram-se na região das "minas do Cuiabá", à beira dos rios (principalmente do Cuiabá), abastecendo os arraiais e povoados e um considerável fluxo de pessoas atraídas pelos descobertos de ouro e por oportunidades de explorar atividades comerciais e produtivas. ${ }^{61}$ Ao norte, "rio Cuiabá acima", em direção à Chapada, também percebemos a espacialização de ambientes rurais.

Muitas unidades produtivas eram descritas como "roças". Apesar do termo "roças" aparentemente fazer referência à agricultura, nestas unidades produtivas desenvolvia-se uma série de atividades. Além do plantio, principalmente de milho e de feijão, também havia criações de pequenos animais como galinhas, porcos e carneiros, e eventualmente, cabeças de gado, praticando-se ainda a caça, a pesca e outras atividades extrativistas. Esta, inclusive, foi uma das razões por optarmos pelo termo "ruralidade", e não atividades agrícolas ou agropastoris, para caracterizar as práticas de reprodução social no meio rural.

A partir da análise de relatos e de outros documentos, percebemos que, no caminho fluvial que ligava São Paulo a Cuiabá, as espacialidades rurais que abasteciam as monções ampliavam-se ao longo do tempo. Cabral Camelo, que fez viagem em 1727, apontou que, no varadouro de Camapuã, havia "duas roças povoadas" e acrescenta,

Esses dois pobres roceiros vivem como em um presídio, com suas armas sempre nas mãos; para irem buscar água, não obstante o terem-na por perto, vão sempre com guardas: no roçar, plantar e colher os mantimentos levam sempre todas as armas, e enquanto vigiam uns trabalham outros, mas sempre com espingardas à mão; e nem com toda esta cautela se

${ }^{60}$ CANAVARROS, Otávio. O poder metropolitano em Cuiabá. Ed da UFMT, 2004, p. 93-94.

${ }^{61}$ Parecer de Rodrigo César de Meneses ao rei d. João V. Lisboa, 08-01-1732, mss., microfilme, rolo 01, doc. 54 (AHU) - NDIHR/UFMT. CAMELO, João Cabral. Notícias práticas das minas do Cuiabá e Goiáses, na Capitania de São Paulo e Cuiabá que dá ao rev. padre Diogo Soares, o capitão João Cabral Camelo, sobre a viagem que fez às minas do Cuiabá no ano de 1727. In: TAUNAY, Affonso de E. História das bandeiras paulistas. Relatos monçoeiros. Tomo III. $2^{\mathrm{a}}$ edição. São Paulo, 1961, p. 135-139. 
livram de que em várias ocasiões lhes tenham os Caiapós morto a alguns: colhem contudo bastante milho e feijão, e o vendem muito bem; quando eu fui venderam a dezesseis e dezoito oitavas o milho; o feijão a vinte; e as galinhas porcos e cabras, como quiseram. A roça de cima tem já canavial e bananal, e está cercada toda de boa estacada (...). ${ }^{62}$

Qualquer documento, e mais especificamente os relatos, deve ser analisado levando em conta uma série de aspectos. Neste relato, há elementos narrativos que estão ligados a um conjunto de "representações" que influem de forma determinante na construção do relato. No entanto, como aponta Carlo Ginzburg, os elementos narrativos são indissociáveis dos indícios, sinais que os documentos deixam sobre o passado. Não lemos o relato de Camelo como testemunho fiel, ou como afirma Ginzburg, "como janelas escancaradas”, mas também, não podemos admitir que a percepção da dimensão narrativa implique em ler os documentos como "muros que obstruem a visão". Os documentos podem ser analisados como "espelhos deformantes". ${ }^{3}$

A territorialização portuguesa no varadouro de Camapuã significou a desterritorialização dos índios Caiapó de parte do seu extenso território, o que fica bastante evidente tanto na documentação quanto na cartografia da época. $\mathrm{O}$ fato de Camelo fazer referência a "dois pobres roceiros" que vivem em Camapuã não deve nos levar a conclusões precipitadas sobre as características das paisagens rurais do varadouro. As roças de Camapuã contavam com a presença de trabalhadores escravos. Devido ao caráter lacunar da documentação não temos uma estimativa do número, mas, em 1728, um documento aponta que em "Camapuã como no caminho dos Goiazes, nestes poucos anos passados, tem feito os ditos gentios (Caiapó) muitos danos e hostilidades, porque só aos roceiros tem morto quarenta escravos". ${ }^{64}$

Apesar de o documento apontar a morte de "escravos", não é possível afirmar que se tratavam apenas de escravos de origem africana, pois no mesmo

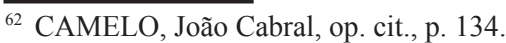

${ }^{63}$ GINZBURG, Carlo. Relações de força: história, retórica prova. São Paulo: Cia das Letras, 2000 , p. 45. "A ideia de que as fontes, se dignas de fé, oferecem um acesso imediato à realidade ou, pelo menos, a um aspecto da realidade, me parece (...) rudimentar. As fontes não são nem janelas escancaradas, como acreditam os positivistas, nem muros que obstruem a visão, como pensam os cépticos: no máximo poderíamos compará-los a espelhos deformantes. A análise da distorção específica de qualquer fonte implica já um elemento construtivo. Mas a construção, (...), não é incompatível com a prova; a projeção de desejo, sem o qual não há pesquisa, não é incompatível com os desmentidos infligidos pelo princípio de realidade. O conhecimento (mesmo o conhecimento histórico) é possível”.

${ }^{64}$ Carta do rei d. João V ao governador Antônio da Silva Caldeira Pimentel. Lisboa, 08-10-1730. Registro de cartas expedidas. Livro C 001, APMT. 
documento fica evidente o "costume" de tomar os índios como escravos. ${ }^{65}$ Fica claro, por outro lado, a marcante presença de escravos africanos, sendo inclusive estes que carregavam em fileira as cargas e empurravam os carros em que se transportavam as canoas que eram atravessadas de um lado a outro do varadouro, em um percurso que durava de quinze a vinte dias. ${ }^{66}$ Além do trabalho escravo, a observação de Camelo de se tratarem de "duas roças povoadas" demonstra que além dos dois "roceiros" e de escravos também outras famílias habitavam o varadouro de Camapuã.

Seguindo o relato de Camelo há evidências de que na medida em que este se aproxima da região das "minas do Cuiabá", havia uma maior densidade de ambientes coloniais, o que pode ser percebido inclusive pelos elementos narrativos do relato de Camelo. Ao entrar no rio Taquari surge o Pantanal,

(...). Abaixo das itaipavas há duas roças, que se lançaram no ano em que eu passei aquelas minas; mas como até aqui chegam os Caiapós, não foram de muita dura: pelo Taquari abaixo se gastam dez ou onze dias, tem vários sangradouros, que formam grandes lagoas no Pantanal. Pantanal chamam os Cuiabanos a umas vargens muito dilatadas, que começando no meio do Taquari, vão acabar quase junto ao mesmo Rio Cuiabá. Este Rio Taquari até o meio tem alguns matos, o mais tudo são campos; dizem que de uma e outra parte há gentios; mas supõe-se que são restos de algumas nações que os sertanistas conquistaram. Deste vi só três bugres, que traziam em sua companhia um Sargento-mor Paulista e eram agigantados. ${ }^{67}$

Na narrativa do mesmo autor, o Pantanal aparece como uma territorialidade construída pelos “cuiabanos". A definição de "vargens muito dilatadas" é apenas o começo da descrição. Na sequência do relato, as características naturais do ambiente dão lugar a um Pantanal inscrito pela conquista portuguesa. O Pantanal emerge como parte de uma epopeia da conquista dos colonizadores, construída por várias tipologias documentais ("cristãos", "civilizados") sobre os índios ("selvagens", "bravios", "gentílicos") e o ambiente ("sertão").

Enquanto a população colonial surge como parte de um processo de expansão, os índios aparecem como "restos de algumas nações". Mas estes elementos narrativos não são (ou não são apenas) recursos literários do autor. O processo de colonização destruiu aldeias inteiras, escravizou homens, mulheres e crianças, ameríndios e africanos, impôs o seu tempo sobre as diferentes temporalidades.

\footnotetext{
${ }^{65}$ Carta do rei d. João V ao governador Antônio da Silva Caldeira Pimentel. Lisboa, 08-10-1730, op. cit.

${ }^{66}$ CAMELO, João Cabral, op. cit., p. 134.

${ }^{67}$ CAMELO, João Cabral, op. cit., p. 135.
} 
As reflexões de Roger Chartier sobre as relações entre práticas e representações apontam para a impossibilidade de dissociar as práticas discursivas das demais práticas sociais. A análise de Chartier nos permite rechaçar, de uma vez só, duas posições antagônicas sobre a análise documental: que os documentos fornecem dados objetivos e inequívocos sobre o "real" e que os escritos sobre o passado expõem apenas a "visão de mundo de seus autores", sendo esta inscrita na subjetividade das categorias intelectuais, não tendo relações com as práticas sociais. ${ }^{68}$ Aliás, fica evidente no relato de Camelo a impossibilidade em dissociar as representações das espacializações. O topônimo Pantanal merece atenção, pois mostra como, em suas narrativas, os colonos luso-americanos "parecem ignorar a tradição precedente tão imbricada no imaginário ocidental, pelas narrativas espanholas e pelas cartas geográficas universais. Nos seus caminhos nomeiam uma nova geografia". ${ }^{69}$ Esta região descrita por Camelo, reconhecida pelos "cuiabanos" como Pantanal, era denominada pelos colonizadores espanhóis do século XVI como mar, lagoa ou terra de Xarayes. ${ }^{70}$

Mesmo admitindo que o relato de Camelo tenha um conteúdo muito rico para uma "fenomenologia do espaço", não podemos deixar de considerar que o autor do relato não escreveu suas "notícias" em um gabinete. Camelo percorreu caminhos, viu, presenciou, sentiu e relatou. Seria ingenuidade afirmar que seu relato é uma descrição objetiva, mas não podemos fechar os olhos para o fato de que há aspectos do relato de Camelo que escapam do campo das construções literárias. Maria de Fátima Costa aponta que "os escritos monçoeiros têm um sentido de relato prático, quase didático, nos quais se procura ensinar a outros viajantes como vencer as agruras do difícil percurso fluvial". ${ }^{71}$ No relato de Camelo encontramos sinais, indícios, evidências da existência de espacialidades rurais e das características destas espacialidades. Ainda no Pantanal, mas agora na passagem pelo rio dos Porrudos (São Lourenço), relata,

\footnotetext{
68 “As estruturas do mundo social não são um dado objetivo, tal como são as categorias intelectuais e psicológicas; todas elas são historicamente produzidas pelas práticas articuladas (políticas, sociais, discursivas) que constroem as figuras. São estas demarcações, e os esquemas que as modelam, que constituem o objeto de uma história cultural levada a repensar completamente a relação tradicionalmente postulada entre o social, identificado com um real bem real, existindo por si próprio, e as representações supostas como o refletindo ou dele se desviando". CHARTIER, Roger, op. cit., p. 27.

${ }^{69}$ COSTA, Maria de Fátima. Notícias de Xarayes. Pantanal entre os séculos XVI a XVIII. Tese de doutorado em História. Departamento de História/FFLCH, USP, 1997, p. 171.

${ }^{70}$ BASTOS, Uacury Ribeiro Assis. Expansão territorial do Brasil colônia no vale do Paraguai (1767-1801). Tese de doutorado em História, Departamento de História/FFLCH, USP, 1972, p. 25.

${ }^{71}$ COSTA, Maria de Fátima, op. cit., p. 171.
} 
Este rio dos Porrudos não cede ao Paraguai na abundância de peixe, porque tem muito e bom, e de toda a casta e também muito abundante de caça, e nele não faltam onças, que têm feito algumas mortes. Vê-se ainda neste um formoso bananal, que foi do gentio que lhe deu o nome, e de onde também foram as primeiras bananeiras para o Cuiabá. ${ }^{72}$

Insistimos, analisando este trecho, que é impossível dissociar os elementos narrativos dos indícios e da materialidade das espacializações. Em quatro palavras - "que foi do gentio" - conseguimos perceber, ao mesmo tempo, a percepção do conquistador de que instaura no passado o domínio (e não a presença) ameríndia na região, como também a espacialização desta concepção na invasão e subjugação de povos ameríndios. Não há, neste sentido, hierarquia entre o que se pode chamar de representações e práticas, mas, assim como já vimos, uma articulação entre práticas, representações e apropriações. O topônimo Pantanal, portanto, não pode ser dissociado do contexto de desterritorialização ameríndia e está ligado à formação de uma identidade territorial das minas do Cuiabá, espacializando as mais diversas práticas de conquista, inclusive as práticas discursivas.

Feitas estas considerações, voltemos ao relato de Camelo. Chegando ao rio que emprestara seu nome à Vila Real, Camelo descreve

Da barra deste rio serão vinte ou vinte dois dias de viagem. Ao quarto ou quinto dia se chega ao Arraial Velho, ou registro, que vem a ser uma roça com muito bom bananal: dia e meio acima desta roça está outra também povoada, e desta até os Morrinhos, que serão sete ou oito dias de viagem, a outras duas que dão bastante milho e feijão; porém, dos Morrinhos até a vila, que são seis ou sete dias, quase todo este rio está cercado de roças e fazendas, como também quatro ou cinco acima da mesma vila, e em todas se plantam milho e feijão, em dois meses do ano março e setembro; dão também excelentes mandiocas, de que se faz farinha; há nelas muitas e melhores bananas que as destas minas, e as suas bananas são mais suaves e de melhor gosto: tem já muitas melancias, e quase todo o ano, só os melões não produzem em tanta abundância; as batatas são singulares e não menos o são os fumos para o tabaco e pito. ${ }^{73}$

João Cabral aponta que as roças eram plantadas duas vezes ao ano, março e setembro, o que era possível graças à possibilidade de ocupar grandes áreas para o plantio, pois era necessário um conjunto de ambientes com características diferenciadas. Devemos lembrar que, nesta época em Mato Grosso, assim como em muitas áreas de floresta tropical, o plantio de muitos gêneros era feito por

\footnotetext{
${ }^{72}$ CAMELO, João Cabral, op. cit., p. 138.

${ }^{73}$ CAMELO, João Cabral, op. cit., p. 138-139.
} 
meio de roças coivaradas que, devido à abundância da terra e à pouca fertilidade dos solos, necessitavam de longos pousios, exceto nas roças de beira rio, onde, uma vez desmatada a margem, as águas encarregavam-se de renovar anualmente a fertilidade do solo.

Este plantio em março dava-se justamente à beira dos rios, aproveitando o adubo natural deixado pelas águas da vazante. A plantação em setembro, logo nas primeiras chuvas, era feita em partes mais altas, para que, quando o milho e o feijão estivessem prontos para serem colhidos, por volta de fevereiro, não estivesse sob as águas. Portanto, além de estar estrategicamente na rota das embarcações, a ocupação das beiras dos rios justifica-se pela fertilidade dos solos e pela possibilidade de plantio em épocas diferenciadas.

Além das águas dos rios e dos córregos também as chuvas eram fundamentais para as atividades agrícolas. Em uma agricultura como a praticada neste período, a regularidade destes ciclos entre cheias e vazantes era fundamental. Uma não continuidade das chuvas a partir de setembro obrigaria o replantio das roças. ${ }^{74}$

João Cabral faz referências ao "Arraial Velho, ou registro". Localizando-o cerca de cinco a seis dias de viagem pelo rio Cuiabá, onde também havia o "porto do Borralho". Era um local importante para os sertanistas abastecerem-se para o restante da viagem, mas também era o local do "registro", ou seja, era onde os homens e mulheres que faziam parte das tropas pagavam tributos sobre os valores, pesos e medidas de suas cargas e escravos. Os Morrinhos provavelmente fazem referência a onde atualmente localiza-se a cidade de Barão de Melgaço, no rio Cuiabá abaixo, também outro importante local de abastecimento.

O mesmo autor diferencia roças e fazendas. Apesar de esta diferenciação estar presente tanto na documentação oficial quanto nos relatos, muitas vezes é difícil diferenciar e caracterizar as roças e as fazendas. Os termos roça e roceiro, de uma forma geral, caracterizam ambientes rurais de pequena produção encabeçados por livres pobres. Já vimos, no entanto, que apesar da produção do varadouro de Camapuã ser marcadamente escravista, a forma de espacialização e os senhores destes escravos são descritos por Camelo como "roças" e "roceiros". Há outras referências que caracterizam o ambiente rural de Camapuã como uma fazenda pertencente a dois sócios. ${ }^{75}$

Não percebemos o contrário, ou seja, não há referências de fazendas de pequenos produtores não escravistas. Apesar destas ponderações acerca dos

\footnotetext{
${ }^{74}$ REBELO, Gervásio Leite, op. cit., p. 129.

${ }^{75}$ TAUNAY, Affonso de E. História das bandeiras paulistas. Relatos monçoeiros. Tomo III. $2^{\mathrm{a}}$ edição. São Paulo: Ed. Melhoramentos, 1923.
} 
limites de uma caracterização precisa de roças e fazendas, acreditamos ser válida a percepção de uma e outra como ambientes rurais distintos. Diferenciação esta que se constitui em instrumento analítico para a análise das relações entre a produção escravista em larga escala e a produção rural dos livres pobres (que poderiam eventualmente utilizar o trabalho escravo em uma escala menor). Além das roças e fazendas, Camelo também cita os engenhos. Quando chegou a Cuiabá em 1727, apontou a existência de apenas um engenho; em 1730, segundo ele, já eram cinco engenhos no termo da Vila Real.

Segundo o mesmo autor, os principais produtos agrícolas eram o milho e o feijão, mas além destes, mandioca, banana, melancia, batata, melão e fumo. Entre estes podemos destacar o fumo como um produto que, ao lado da produção de aguardente, que veremos adiante, alargava as potencialidades do comércio, já que se tratavam de mercadorias de grande circulação não só na América, mas no Império português como um todo. A pesca era uma atividade desenvolvida desde o princípio da colonização, reproduzindo práticas portuguesas de longa duração. O peixe, fresco ou salgado, era mercadoria no mercado local. ${ }^{76}$

Um produto que é revelador de características destes ambientes rurais no "oeste do Império ocidental português” é a mandioca. Curiosamente, em 1726, Gervásio Rebelo, secretário do governador de São Paulo, não cita a farinha de mandioca entre as mercadorias vendidas no caminho fluvial e no arraial do Senhor Bom Jesus. Apesar da aparente banalidade da questão, o fato de ignorar-se que a farinha de mandioca foi importante elemento da produção local teve implicações sobre a análise da formação de ambientes rurais no centro da América do Sul. Segundo Sérgio Buarque de Holanda", em Cuiabá, durante a visita do governador Rodrigo Cezar de Menezes, (...), a farinha de mandioca não é sequer mencionada, (...), no rol dos gêneros que de ordinário se consumiam". Para Holanda, a preferência do milho sobre a mandioca relacionava-se à "mobilidade que, por longo tempo, distinguiu a gente do planalto" e acrescenta que "o milho além de poder ser transportado a distâncias consideráveis em grãos, que tomavam pouco espaço para o transporte, oferecia a vantagem de começar a produzir cinco e seis meses ou menos". ${ }^{77}$

Sem dúvida, as evidências documentais apontam que o milho era um dos principais elementos da dieta nas "minas do Cuiabá” e não só servia de alimento, com múltiplas derivações, para os homens e mulheres que viviam na região, como

\footnotetext{
${ }^{76}$ CAMELO, João Cabral, op. cit., p. 139.

77 HOLANDA, Sérgio Buarque, op. cit., p. 186.
} 
também era o principal alimento dos animais domésticos. A associação direta do milho com a mobilidade social, no entanto, é perigosa e leva a grandes equívocos.

Primeiramente, assim como mostra Camelo, havia plantações de mandioca, e finalmente, e o mais importante, é que mesmo que houvesse uma parte da população colonial que transitasse continuamente entre diferentes áreas de exploração aurífera, desenvolvendo práticas sertanistas, havia uma fixidez do meio rural que, inclusive, dava suporte a esta mobilidade, o que fica evidente em vasta documentação, como nas cartas de sesmarias e nas correspondências entre autoridades locais e outras partes do Império português.

Apesar da fixidez, a produção do meio rural sofria, "nas minas do Cuiabá", o que é inerente às práticas rurais, com a falta de chuvas. Em 1727, a região passava por um período difícil de longa estiagem que prejudicava não só as atividades rurais, como também a mineração e inflacionava os preços. ${ }^{78}$ Além da estiagem havia também "pragas". Segundo José Barbosa de Sá:

Crescia o milho que se plantava na terra e antes de nascer o comiam os ratos depois de nascido o que escapava dos ratos o destruíam os gafanhotos o que chegava a espigar brotava o sabugo sem grão e algum que granava o comiam os pássaros que era necessário colhê-lo verde: o que acontecia aos feijões e a tudo o mais que se plantava na terra. ${ }^{79}$

Excetuando-se a possibilidade de Cuiabá e seu termo terem sido abatidos pelas bíblicas pragas do Egito, o relato de Barboza de Sá é bastante figurativo. As observações deste cronista são referências de quase todos os trabalhos que tratam do período em Mato Grosso. A maioria dos autores que citaram passagens das crônicas de Barboza de Sá utilizou-as como dado objetivo para apresentar aspectos sociais e econômicos das primeiras décadas da colonização portuguesa em Mato Grosso. ${ }^{80}$ As ideias reproduzidas por Barbosa de Sá neste trecho remetem a um conjunto de representações bastante amplo e que tinham o objetivo de evidenciar, no limite, as dificuldades e o "sofrimento" dos colonos. Mas trechos do mesmo documento, e a relação deste com outros, oferecem indícios diversos.

O destaque que Barbosa de Sá atribui às pragas, à fome e às doenças estava profundamente ligado com aspectos negativos que este atribui ao período em que

${ }^{78}$ REBELO, Gervásio Leite, op. cit., p. 129. Carta de Rodrigo César de Meneses ao rei d. João V; Vila Real do Senhor Bom Jesus do Cuiabá, 03-1727; mss., microfilme, rolo 01, doc. 10 (AHU)DIHR/UFMT.

${ }^{79}$ SÁ, José Barbosa de, op. cit., 18.

${ }^{80}$ ABREU, Capistrano. Capitulos de história colonial. São Paulo: Publifolha, 2000, p. 165. PINTO, Virgílio Noya. O ouro brasileiro e o comércio anglo-português. São Paulo: Cia. Editora Nacional, 1979, p. 87. HOLANDA, Sérgio Buarque, op. cit., p. 144. 
Rodrigo César de Meneses esteve em Cuiabá, período em que foi fundada a Vila Real e a cobrança de tributos, que já existia, foi intensificada. De acordo com Sá, logo após a partida do capitão-general em 1728, "melhorou tudo, cessaram as excomunhões, execuções, lágrimas e gemidos, pragas, fomes, enredos e mecillanias (sic) apareceu logo ouro produziram os mantimentos melhoraram os enfermos". ${ }^{81}$

Ora, ao ler este trecho fica claro que o texto de Sá, como qualquer outro, não pode ser lido sem muito cuidado, o que não anula sua importância, pelo contrário, possibilita perceber como as relações de poder perpassam a documentação do período e constroem imagens heterogêneas sobre os espaços. O fato de Barbosa de Sá associar o período de melhorias nas atividades produtivas e também de bem-estar à saída da Rodrigo César de Meneses não pode nos levar a ignorar seu valor como indício, pois outras evidências documentais apontam que, entre 1728 e 1730 , encerrou-se o período de secas. ${ }^{82}$

Voltando às pragas, outro trecho do relato de Barbosa de Sá sugere que estas, embora dificultassem e diminuíssem a produtividade agrícola, eram combatidas pelos colonos. Segundo Sá, “os ratos eram tantos que se não podia deles livrar coisa alguma (...) trouxeram de povoado [São Paulo] um casal de gatos vendeu-os o dono por uma libra de ouro (...), logo houve tantos que perderam o valor". ${ }^{83}$

Ao leste da Vila Real, nas espacialidades rurais no rio São Lourenço, as roças invadiam cada vez mais as margens dos rios em territórios dos índios Bororo. Ao norte, em território Pareci, os colonos avançavam em direção à Chapada (atual Chapada dos Guimarães) onde se espacializavam, especialmente, lavouras de cana-de-açúcar. Além de invadir os territórios ameríndios para reproduzir atividades rurais, o aprisionamento/venda de índios era uma lucrativa atividade econômica. Com a intensificação do processo de colonização, esta atividade não perdeu força, pelo contrário, expandia-se cada vez mais, engendrando a conquista.

Para os planos geopolíticos portugueses, a introdução de ameríndios na sociedade colonial, pelo batismo, e a inserção destes nesta sociedade como súditos do rei português eram parte do que se convencionou chamar de política de povoamento. Para a região em questão, mais apropriado seria política de colonização, já que a densidade demográfica, se levarmos em conta as sociedades ameríndias (maioria absoluta da população) diminuiu consideravelmente nas áreas colonizadas.

\footnotetext{
${ }^{81}$ SÁ, José Barbosa de, op. cit., p. 25. Além desta passagem, há outras bastante curiosas que mostram o quanto Sá utiliza-se de recursos discursivos que exploram de forma positiva ou negativa a relação entre ações humanas e respostas divinas; algumas passagens chegam a ser verdadeiras fábulas.

${ }^{82}$ Carta-relatório de Rodrigo César de Menezes; Cuiabá, 28-04-1728 apud CANAVARROS, Otávio. O poder metropolitano em Cuiabá (...), op. cit., p. 157.

${ }^{83}$ SÁ, José Barbosa de, op. cit., p. 18.
} 
Foi a expansão das atividades sertanistas, particularmente o preamento de ameríndios Pareci que levaram às conquistas das minas do Mato Grosso a oeste das minas do Cuiabá, o que teve impacto sobre os ambientes rurais, já que a Vila Real se tornou entreposto para os arraiais do Mato Grosso. O caminho de terra aberto entre Cuiabá e Mato Grosso, em 1736, agilizou as comunicações e intensificou o comércio. Nos primeiros anos, os produtos transportados de Cuiabá a Mato Grosso eram conduzidos "nas costas dos negros", segundo as autoridades, "por não haver cavalos nestas minas". ${ }^{84}$ Sabemos que havia cavalos, mas talvez não em número suficiente para o transporte de mercadorias, situação que se alteraria com a abertura de outro caminho, bem mais longo, de Goiás a Cuiabá, e que teve grande impacto nas relações produtivas e comerciais.

A abertura de um caminho de terra que efetivasse a comunicação entre Cuiabá e Goiás era reivindicada por vários motivos, entre eles a dependência do comércio de gado e cavalos com os Mbayá-Guaycuru. Uma “junta”, que reunia os membros da câmara da Vila Real e pessoas localmente influentes, discutiu a questão.

A segunda (junta) foi sobre fazer ou não comércio com o gentio cavaleiro para se meterem cavalos nestas Minas, bem necessários são porque não há dez capazes de se montar neles por velhos; mas este comércio com o gentio é muito arriscado, inconstante; abrindo-se caminho para as dos Goiaz como se tem intentado, virá cavalaria em abundância. ${ }^{85}$

A historiografia construiu uma imagem da rota Goiás-Cuiabá como uma via de mão-única na qual apenas trazia-se gado, cavalos e muares para as minas do Cuiabá e do Mato Grosso. No entanto, a produção de mercadorias de alto potencial mercantil, como a produção de aguardente em escala considerável e de tabaco, por exemplo, são indícios de que a produção do termo da Vila Real estava ligada a relações comerciais mais amplas com outras praças comerciais da América portuguesa. Até a abertura do caminho de terra de Goiás a Cuiabá, a única rota comercial que ligava a região ao litoral era a o caminho monçoeiro. Depois da abertura destes caminhos, os comerciantes das monções tiveram que concorrer com comerciantes que percorriam os caminhos de terra, que integravam os dois distritos (Cuiabá e Mato Grosso) do termo da Vila Real de Cuiabá, não apenas a Goiás, mas também ao litoral sudeste e nordeste da colônia.

\footnotetext{
${ }^{84}$ Carta de João Gonçalves Pereira ao rei d. João V. Vila Real do Senhor Bom Jesus do Cuiabá, 08-09-1739. mss., microfilme, rolo 02, doc. 127 (AHU) - NDIHR/UFMT.

${ }^{85}$ Carta do ouvidor João Gonçalves Pereira ao rei d. João V; Vila Real do Senhor Bom Jesus do Cuiabá, 07-10-1736; mss., microfilme, rolo 01, doc. 89 (AHU) - NDIHR/UFMT.
} 
Contudo, é fato que a abertura do caminho de terra possibilitou a entrada de gado, muares e cavalos em grande escala para o termo da Vila Real do Senhor Bom Jesus do Cuiabá,

Com cinco dias de viagem deste rio Cuiabá para o novo descobrimento do Mato Grosso, onde vou à (...) do novo sistema de capitação, me veio a notícia de ter à vila o Capitão Antonio de Pinho de Azevedo de volta das Minas dos Goyazes para onde tinha partido em junho do ano passado com emprego de abrir caminho destas para aquelas, o que se dificultava por ser povoado de numeroso gentio, e como se conseguiu esta empresa com a ida, e volta do sobredito, e de seus camaradas, dou a V. Majestade esta conta (...) este caminho há de servir de grande utilidade à fazenda de Vossa Majestade, à extensão dos seus domínios, e foi de grande gosto para todos os moradores destas, e daquelas Minas; e pelo mesmo caminho me consta vieram quatrocentos e tantos cavalos de que havia grande necessidade nestas terras para com eles se continuarem o novo descobrimento do Mato Grosso ${ }^{86}$

O fluxo não somente de cavalos, mas de gado e outras mercadorias intensificouse ao longo dos anos. ${ }^{87}$ Apesar de já haver gado em Cuiabá desde o princípio da colonização, foi somente após a abertura deste caminho de terra que a região pode contar com a quantidade de gado suficiente para a formação de grandes "currais".

A introdução do gado em grande escala provocou transformações gradativas na paisagem do Pantanal. Além das roças, fazendas de produção agrícola e engenhos, também os currais passaram a compor o mosaico de formas de unidades produtivas do meio rural, além da perceptível introdução do gado nas pequenas propriedades. Os grandes latifúndios abertos pela elite local mostram um investimento de capitais advindos da mineração na pecuária extensiva. ${ }^{88}$

A partir principalmente da década de 1740, formaram-se grandes latifúndios na parte norte do Pantanal, mudando inclusive o perfil dos pedidos de sesmarias para a região, antes principalmente para a criação de porcos e cultivo de roças e agora também para a formação de currais. A posse oficial por meio de sesmarias não era a única maneira de expandir os domínios dos criadores de gado. Em documento datado de 1741, o provedor da Fazenda Real reclama ao rei sobre a grande quantidade de terras que não foram doadas como sesmarias e eram ocupadas por poucos senhores, apontando que

${ }^{86}$ Carta do ouvidor João Gonçalves Pereira ao rei [d. João V] em que informa que fez publicar um edital para moderar o aprisionamento de índios. Vila Real do Senhor Bom Jesus do Cuiabá, 13-09-1737; mss., microfilme, rolo 01, doc. 101 (AHU) - NDIHR/UFMT.

${ }^{87}$ Requerimento do capitão Antonio Pinho de Azevedo ao rei.

${ }^{88}$ SIQUEIRA, op. cit., p. 37-40. 
Cada um quer ser o senhor de meio mundo para trazer os seus gados e não dão lugar para que se façam mais fazendas dele, o que é muito_prejudicial ao estabelecimento da terra (...). Me parece ser conveniente ao real serviço de v. majestade (...) que cada um seja conservado nas terras que estão de posse (...). Com só dois currais de muito pouco gado se tomam mais de vinte léguas de terra em que se podiam fundar muitos para a fartura da terra e aumento dos dízimos. ${ }^{89}$

A citação deixa evidente a complexidade da relação entre a formação de currais e a administração portuguesa. Embora a concessão de privilégios à elite local, que, aliás, ocupava a câmara da Vila Real, fosse evidente, para a Coroa portuguesa era fundamental a posse efetiva da terra, o aumento da produção rural e da arrecadação.

Em concomitância com as grandes fazendas, expandiam-se também os engenhos, fazendas e roças. Entre 1730 e 1750, os engenhos passaram nas minas do Cuiabá de cinco para dezesseis, que absorviam cada um a média de 25 escravos africanos. Os "senhores de engenho", como eram referenciados na documentação, constituíam parte importante da elite local.

A formação de ambientes rurais no centro da América do Sul, nas primeiras décadas de colonização portuguesa, engendrou ambientes rurais diversos, tanto do ponto de vista das paisagens rurais quanto da diversidade de agentes sociais que encontraram nestas atividades possibilidades de reprodução social e econômica. A expansão das conquistas e a consolidação da posição portuguesa iriam cada vez mais inserir esta "ruralidade" no âmbito da América lusitana e do Império português como um todo, articulando-se, por exemplo, a geografia política da Coroa em relação aos seus territórios ultramarinos, que seguia o princípio do uti possidetis, ou seja, o direito de posse dos territórios conquistados, princípio fundamental que orientou o Tratado de Madrid.

Em muitas das roças reproduziam-se formas camponesas de produção que possibilitavam a reprodução social e econômica de uma grande parcela da população livre pobre das minas do Cuiabá. Os produtos das roças não serviam apenas para a "subsistência", mas abasteciam o mercado interno e serviam como fontes de lucro para os comerciantes. Cabral Camelo apontou, em 1730, que no porto geral do Cuiabá "assistem vários brancos comprando milho e feijão aos roceiros para mandarem a vender; outros o vendem por comissão, com todo o

${ }^{89}$ Parecer do Conselho Ultramarino ao rei d. João V AHU-Mato Grosso, cx. 3, doc. 5 V. Lisboa, 09-02-1741. mss., microfilme, rolo 03, doc. 144 (AHU) - NDIHR/UFMT. 
mais mantimento; e alguns se ocupam só da pesca que não lhe rendem menos". ${ }^{90}$ Mais que isto, essas espacialidades camponesas constituíram, ao longo dos anos, ambientes sociais onde se atualizam tradições e se reproduzem práticas de longa duração que dão sentido e significado às comunidades rurais de Mato Grosso e do Pantanal.

\section{Palavras finais}

Sobre as terras alagadiças do centro da América do Sul construiu-se o Pantanal. Antes do milho, do feijão, da cana-de-açúcar, dos porcos, galinhas e gado, das roças, fazendas, engenhos e currais existiam terras alagadiças, milhares de ameríndios, Bororo, Kaiapó, Payaguá, Guató, Guaná, Guaykuru e outros, inúmeros, que territorializavam suas práticas. Depois, no século XVI, surgiu o mar de Xarayes, invenção espanhola. Contudo, foram os colonos paulistas, portugueses, sertanistas, comerciantes, roceiros, fazendeiros, senhores de engenho, ameríndios reterritorializados, africanos (escravos e forros) que provocaram a emergência do Pantanal, que não significou o fim da história precedente, mas a desterritorialização de povos ameríndios e a territorialização de uma sociedade colonial, a qual estes mesmos ameríndios, de variadas formas, passaram a compor. Os invasores, vassalos da Coroa portuguesa, inventaram o Pantanal, não apenas nas práticas discursivas (relatos, crônicas e correspondências), mas também no contato, muitas vezes conflituoso, com os povos indígenas, na construção de ranchos, de casas, no plantio de roças, nos currais de gado, na exploração do trabalho compulsório, de negros e índios, na exploração do ambiente e em sua transformação progressiva e irreversível.

Analisar a construção histórica do Pantanal não é um culto ao passado, mas a percepção da necessidade de compreender a complexidade do presente, de desconstruir discursos e imagens forjadas em uma memória que silencia vozes e deslegitima práticas reproduzidas secularmente. Compreender o processo de sua construção significa romper com visões e rótulos e mergulhar em uma história tão profunda e extensa quanto as águas que se movimentam ininterruptamente no centro da América do Sul.

Recebido: 05/01/2010 - Aprovado: 24/02/2011.

${ }^{90}$ CAMELO, João Cabral, op. cit., p. 139. 